During the War of 1914-18 he enlisted as a private in the Royal Garrison Artillery and saw service in Flanders and France. $\mathrm{He}$ was wounded and gassed in 1917 , and later received a commission; but he never afterwards enjoyed robüst health and for the last ten years of his life he suffered acutely from diabetes.

In 1922 Tattersall was appointed professor of zoology and comparative anatomy at University College, Cardiff, a post he held throughout the remainder of his life. Starting with only a single post-intermediate student, he and the able staff he gathered around him succeeded in building up a flourishing school of zoology, and shortly before the present War he had sixteen honours and nine research students, with sixty students in the final class. As a teacher of zoology Tattersall had outstanding qualities. With a broad and comprehensive knowledge of his subject he combined the gift of inspiring others with his own unquenchable enthusiasm, and by his simple unassuming ways he won the devotion of his students. He insisted on the importance of field work, and for a long series of years he regularly took a party of students to Loch Ine in Co. Cork. Last May, the twenty-first anniversary of his appointment at Cardiff was commemorated, a celebration attended by 121 of his old students, while eighty others sent cables and telegrams of congratulation.

In the course of his busy life at Cardiff, Tattersall was for seventeen years a member of the Court and Council of the National Museum of Wales, and many universities called on his services as external examiner. $\mathrm{He}$ edited the natural history volume of the Glamorgan County History and served as president of the Cardiff Scientific Society. At University College he was for a time dean of the Faculty of Science and latterly deputy principal. He had been a member of the British Association for more than thirty years, and there was scarcely a meeting he did not attend. $\mathrm{He}$ travelled with the Association to Australia and Tasmania, to Canada and to South Africa, and went to India as delegate to the Indian Science Congress. $\mathrm{He}$ served as secretary and recorder to Section D, of which in 1939 he was president-elect.

Tattersall will long be remembered as our foremost authority on certain groups of Crustacea-principally the Isopoda, Amphipoda, Tanaidacea, Mysidacea and Euphausiacea. He was the ideal systematist, careful, thorough and methodical in everything he undertook, and with that well-balanced outlook that sees in taxonomy a means to an end rather than the end itself. Above all he was a prodigious worker. Busily occupied throughout his life with important educational work, he always found time to continue his personal studies, and the steady stream of valuable papers which he contributed over a span of forty years is a monument to his industry and ability. Reports by him are to be found among the results of almost every marine biological expedition which has set out from Great Britain during the present century, and from all parts of the world collections were sent to him for examination and description. $\mathrm{He}$ was a naturalist in the best sense of the term; interested as much in the development, habits and distribution of species as in their identification, and taking immense trouble, as in his latest paper on the relict fauna of Ennerdale Water, to find a logical interpretation of his results. In addition to his work on Crustacea he made important contributions to our knowledge of the Cephalochorda and Enteropneusta; he was the first to trace the life-history of the periwinkle, and he described the very remarkable larvæ of the starfish Luidia.

At the beginning of the present War he had just completed the manuscript of a volume on the Mysidacea for Bronn's "Thierreich", and since then he finished a report, to which he had devoted four years of work, on a large collection of Schizopods from the American Museum of Natural History. There are hopes that the Ray Society monograph of British Mysidacea, on which he was recently engaged, is sufficiently advanced for publication.

Tattersall married Olive Selden Attride in 1916, and much of the fruitful work that he was able to undertake in his long years of illness is due to her unremitting care and devotion. As a student of science she was able to give him very substantial assistance, and she herself drew nearly all figures which illustrate his papers.

In Great Britain Tattersall seems not to have been appreciated at his full worth : a foreign zoologist once asked me why it was so. Perhaps it was partly because of his unassuming modesty, his lack of 'push' and hatred of self-advertisement, his contentment in the interest of his subject and in the satisfaction that comes of honest work faithfully performed. But in part, I believe, it was because with new methods of approach in zoology we have been led to underrate-as being old-fashioned-the fundamental work of the naturalist in which Tattersall showed such skill. Yet he has left a permanent mark on the literature of his subject, and his name will be honourably remembered when much that is modern has passed into forgetfulness. His many friends will remember him for his genial, goodhumoured outlook on life and personal charm, for his intellectual honesty and for the cheerful courage with which he faced adversity. STANLEY KeMP.

\section{Mr. J. J. A. Jones}

WE regret to record the death on November 1 of Mr. John Jenkin Ashton Jones, of the Central Research Department of the United Steel Companies Ltd., Sheffield, and well known in metallurgical research circles.

John Jones was born in 1894, and graduated from Aberystwyth in 1915. Shortly afterwards he joined the Royal Welch Fusiliers and saw active service in the War of 1914-18, during which he was awarded the Military Medal. In 1917 his military service wes terminated as the result of wounds, and he joined the Research Department at Woolwich, where he assisted Dr. R. H. Greaves. In conjunction with the latter he presented four papers before the Iron and Steel Institute, of which he became a member in 1920 . He was co-author of one other paper, and in his own name contributed six further papers to the Institute.

In $1930 \mathrm{Mr}$. Jones joined the United Steel Companies Ltd. and, with Dr. T. Swinden, director of research, he took a large part in planning the Central Research Department of that group at Stocksbridge. When the Central Research Department opened he became the manager, a post he held to his death. He leaves a widow and a son and daughter.

Mr. Jones represented the best type of scientific worker, and the quality of his scientific papers needs no elaboration. He did much other valuable work which was not so well known. His quiet yet forceful personality and the multiplicity of his contacts gained him many friends, to whom his many other qualities endeared him. As an example of his modest self- 
effacing personality, it may be noted that many who knew him intimately were quite unaware of his distinguished military record. His death will be deeply felt by all who were in contact with him in personal, business and scientific relationships.

Ww regret to announce the following deaths :

Dr. Cecil C. Jones, president and chancellor of the University of New Brunswick, where he was profassor of mathematics during 1906-31, on August 19 , aged seventy-one.
Mr. G. W. Littlehales, hydrographic engineer to the U.S. Hydrographic Office during 1900-32, on August 12, aged eighty-two.

Mr. F. S. Marvin, formerly a staff inspector of the Board of Education, and author of works on the relation of science to civilization, on November 14, aged eighty.

Sir William Noble, a director of the General Electric Co., Ltd., and formerly engineer-in-chief of the General Post Office, on November 10, aged eighty-two.

\section{NEWS}

\section{A Minister of Reconstruction in Great Britain}

THE appointment of Lord Woolton as Minister of Reconstruction with a seat in the War Cabinet follows naturally on Mr. Churchill's declaration in his Mansion House speech on November 9 that it was "a definite part of the duty" and responsibility of this National Government to have its plans perfected in a vast and practical scheme to make sure that in the years immediately following the War there will be food, work, and homes for all. ... No party doctrines or party prejudices or vested interests shall stand in the way of the simple duty of providing before the end of the War for food, work, and homes. They must be prepared now during the War. These plans must be prepared and they must come into action, just like when war breaks out general mobilization is declared. They must come into action as soon as victory is won. On this far-reaching work His Majesty's Government are now concentrating all the energies that can be spared from the actual struggle with the enemy." It may, of course, be inferred that the removal of Lord Woolton from a post.which he has filled with such conspicuous success is an indication that $\mathrm{Mr}$. Churchill does not expect the food problem again to become acute. It is equally an indication of the Prime Minister's assent to the principle that preparation for post-war reconstruction has become an urgent necessity and of the importance which he attaches to the Ministry of Reconstruction.

Sir William Jowitt, who as Minister without Portfolio has hitherto been "charged with the duties of reconstruction", will assist Lord Woolton, and the introduction of new blood at the Ministry of Health, which has so much to do with housing, in the person of Mr. H. U. Willink, may be a further indication of the importance now officially attached to reconstruction. The Government's acceptance; in principle, of Lord Balfour's demand last week for early legislation to permit the prompt acquisition of reconstruction areas "at prices related to pre-war values" gave the impression that this obvious and essential measure will soon be made law. The further admission drawn from Lord Snell that "the Government accepts the principle of national planning without qualification", and the Barlow Commission's planning proposals with qualifications, is also reassuring; while in reply to a question from Mr. John Parker on November 10 the Prime Minister denied that the vesting in the State of the rights of development in all land outside built-up areas (proposed by the Uthwatt Committee) was barred as a possible subject of legislation in the present Parliament because of its controversial character.

\section{nd VIEW S}

The precise scope of Lord Woolton's work has not yet been explained. It may be presumed to be administrative rather than the originating of policy, and that Lord Woolton will be principally engaged in supervising and co-ordinating the Government's plans for food, work and homes. Lord Woolton may not have as wide a scope as Lord Addison in 1917 for his task in focusing all the departmental activities, but in sorting out priorities and in seeing that all the necessary legislation is prepared, including laying out the structure of the new social security scheme and forcing concrete decisions on physical planning and in housing, there is ample scope for Lord Woolton's active mind and administrative resource. Whether or not his responsibilities extend to demobilization and to all the policies that are comprised in full employment, it is a great asset to have in charge of reconstruction a man free from Party ties, and the path to agreement on a common programme should be easier.

\section{Centenary of Ferdinand R. Hassler, 1770-1843}

ON November 20, 1843, the death occurred of the Swiss-American mathematician and geodesist, Ferdin. and Rudolph Hassler, who was the first superin. tendent of the United States Coast Survey, now the United States Coast and Geodetic Survey. To-day the Survey is responsible for hydrographic, geodetic, tidal, magnetic and seismological work throughout the whole of the United States dominions from Florida to the Aleutians, but when it was founded the United States only fronted the Atlantic seaboard. The suggestion for the Survey came from the American Philosophical Society, the recommenda. tions of which were adopted by President Jefferson, and it was through the Society that Hassler became connected with it when Congress on February 10, 1807, passed the necessary law. Hassler had only been in America two years then, but he had taken with him a library of more than 3,000 volumes and a good collection of instruments, and it was his interest in science which had led to his contact with the members of the Philosophical Society.

Hassler was born in Aarau, Switzerland, on October 7,1770 , and was the son of a well-to-do watchmaker. At the University of Berne he gained a knowledge of mathematics and surveying and afterwards was engaged on a trigonometrical survey of Switzerland. $\mathrm{He}$ married in 1798, and in 1805, owing to the political unrest of the time, joined a party of emigrants who planned to settle in the southern States. On their arrival in Philadelphia the would-be colonists met with various difficulties, but Hassler's scientific attainments stood him in good stead. Hassler's 